\title{
Orthodox actors and equal opportunities policies in the Republic of Moldova in the context of the transformation of post-Soviet societies
}

\section{T} his article examines how the key Orthodox actors in Moldova have reacted to challenging equal opportunities legislation. The author suggests, on the basis of an economic approach to religion, that under the conditions of a deregulated religious market they use various strategies to promote their agendas. The Moldovan Orthodox Church (the Metropolitanate of Moldova), autonomous within the Russian Orthodox Church, previously relied on making private bargains with the government; but this policy ended with the adoption of the 2013 Law on Ensuring Equality in the Republic of Moldova. Now the Metropolitanate tries to assimilate the strategies of direct action, but without success. The so-called 'non-mentioning' radicals, technically being part of the Metropolitanate of Moldova, but not praying for its bishop, are involved in direct political activism - from setting up protest camps to street fighting - to confront de-stigmatization of homosexuality. The Bessarabian Metropolitanate of the Romanian Orthodox Church utilizes the strategies of European 'public' churches and gains influence through performing some useful social functions. This article concludes that all actors have their own advantages and weaknesses; nevertheless, so far the Metropolitanate of Moldova remains the strongest; while the other competitors are serving specific religious niches, it is this body which still possesses the potential to influence society more broadly.

\section{Introduction ${ }^{1}$}

Moldovan society ${ }^{2}$ is currently in a process of post-socialist transformation which has already become the subject of a number of academic studies (see, e.g., Iordache 2018; Ganzevoort and Sremac 2017; Bilic 2016; Slootmaeckers et al. 2016; Sremac and Ganzevoort 2015; Ayoub and Paternotte 2014). Pressure from the outside, known as Europeanisation brings about a more rapid change than would have happened 'naturally'. The sphere of sexual morality, including domestic violence, gender roles, and the destigmatization of the LGBT community are becoming particularly important. Within the last two decades or less, profound changes in this area have affected the Western world: even in supposedly liberal France thousands have protested against same-sex marriages. It is no surprise that post-socialist states, living in a state of uncertainty between European integration, a socialist past and the impact of nationalist myths, experience problems with adopting non-discriminatory policies from Europe.

1 This research has been supported by the Russian Foundation for Basic Research, Grant no. 18-011-00598.

2 The research does not cover the self-proclaimed Transnistrian Republic. 
In Moldova legally securing some rights for the LGBT community (in no way same-sex partnership) has provoked a fierce social movement of counter-reaction. Joining the ongoing discussion on the topic of the LGBT community has provided Orthodox actors with an opportunity to reach a wider portion of society than it has been able to before. ${ }^{3}$

This article aims at uncovering how the key Orthodox actors have reacted to the challenge of equal opportunities legislation, and to evaluate the strategies they use to mobilize supporters for their cause. The key actors are the Moldovan Orthodox Church (the Metropolitanate of Moldova) autonomous within the Russian Orthodox Church, and the Bessarabian Metropolitanate of the Romanian Orthodox Church. Other Orthodox groups (Old Believers, noncanonical jurisdictions) enjoy very limited influence and remain beyond the scope of this publication.

The economic approach to religion (Stark and Bainbridge 1987; Stark and Iannaccone 1994; Iannaccone 1997; Young 1997; Stark and Finke 2000; Chesnut 2003; for a critical survey of the theory see Lehmann 2010; Kargina 2014) allows for conceptualizing multiple Orthodox actors as competing religious producers. In 2011-13 the Republic of Moldova made a transition from being a regulated religious market, where the Metropolitanate of Moldova, according to the UN Special Rapporteur, enjoyed informal privileged treatment (United Nations 2012: 9-10), to more or less free religious competition. Due to the legalisation of Islam in 2011 and amendments made in 2012 to the legislation on

3 They struggle against abortion too, but it was legalized may decades ago in the USSR, and the topic is meaningful only for practicing believers. freedom of conscience, Orthodox Christianity as a whole has found itself in a situation of religious pluralism. While Islamic influence in Moldova remains limited, multiple Protestant denominations represent a serious challenge to Orthodoxy. Besides, the Metropolitanate of Moldova, previously a state-protected 'monopoly', has to compete with alternative 'suppliers'. Those actors, who adjust better to the changed market conditions and win more support, can be evaluated as stronger competitors.

Apart from printed and electronic sources, I rely on observations made during my research visits to Moldova (2011, 2013, 2019); and on ten semi-structured interviews taken at different stages of the research. The Metropolitanate of Moldova is represented by its secretary $\mathrm{Fr}$ Vadim Cheibaş; Chair of the Synodal Youth Department, Fr Octavian Moșin; Fr Nikolai Florinskii and Fr Vitalii Shinkar from the parish of St George in Chișinău; and Fr Vasilie, who insisted on maintaining his anonymity. The radicals, technically being part of the Metropolitanate of Moldova, but not praying for its bishop, are represented by Fr Anatolie Cibric. Fr Ioan Cosoi is the secretary of the Bessarabian Metropolitanate and director of its social projects. I also quote from a previously unpublished 2011 interview with a Moldovan lay theologian Nicolae Fuştei, and with Ian Feldman, president (from 2015) of the Council for the Prevention and Elimination of Discrimination and Ensuring Equality. Interviews and observations are crucial for this research, because religious life in Moldova is scantily documented; therefore, this publication pursues the additional end of collecting descriptive data.

In 2010 the European Union made effective protection from all forms of discrimination - including on the basis of 
sexual orientation - the condition for lifting the visa obligation for citizens of Moldova. The new Law on Ensuring Equality was officially adopted by its parliament in May 2012. The first draft of this document underwent revisions; the final version having been modified to satisfy the demands of the Church. Oleg Efrim, erstwhile Minister of Justice, told me that 'we have taken into consideration all the wishes of the Church except the one that this law should not exist' (Efrim 2013). Sexual orientation-based discrimination was now prohibited only in the sphere of employment - meaning, verbal condemnations of homosexuality could not be legally punished; an amendment was made allowing religious organizations to employ (or not employ) whoever they wanted. Article one of the Law on Ensuring Equality indicates that the provisions of the law are not related to and cannot be interpreted as causing damage to (1) family, based on marriage between a man and a woman, (2) adoption, and (3) 'religious cults and their components in the part related to religious beliefs' (Lex.justice.md 2012). Nevertheless, the law is still seen by the Moldovan Church as unsatisfactory, since it forbids offending individuals on the basis of their homosexuality and obliges all non-religious employers (schools, businesses, etc.) not to discriminate against homosexuals.

The Council for the Prevention and Elimination of Discrimination and Ensuring Equality was established in 2013 to respond to complaints issued by private citizens. Ian Feldman stresses that their activities are mostly focused on the rights of the disabled, and that the largest annual share of LGBT cases has been five per cent (Feldman 2019). Nevertheless, political actors pay most of their attention to these cases. Pride marches have been held in Chișinău since 2013. They are not large, but they are symbolically significant, as they are in all post-socialist countries; these processions, heavily guarded by the police, have already attracted academic attention in the field of what might be called 'Pride studies' (see, e.g., Drissel 2016; Igrutinović et al. 2015).

\section{The Metropolitanate of Moldova: hold the balance until you fall}

The position of the Metropolitanate of Moldova with regard to non-discrimination policies seems uncompromising. In summer 2013 Metropolitan Vladimir (Cantarean) promised to excommunicate politicians who had voted for the Law on Ensuring Equality a month earlier. In September 2014 the Synod issued a 'Condemnation of gay parades and of the consequences of adopting the Law on Ensuring Equal Opportunities', which explicitly accused the government of collaborating with those who promoted sinful behaviour, thus 'targeting the foundation of the most holy values of our people' (Biserica Ortodoxă din Moldova 2014). ${ }^{4}$ No politician, nevertheless, has ever been excommunicated. The Church protested by organising - to counterveil the Pride demonstration - its own rallies. Headed by Metropolitan Vladimir personally, a 'silent march' has been held annually since 2013 as a procession of priests, monastics and families (often with children), as well as of single laypeople singing Orthodox hymns and holding pro-family posters, such as images of the Romanov Holy Royal Family. 5 The marches signify a break from the habitual

4 The document was inspired by protesting activity of the radicals to be discussed below.

5 Such processions became characteristic of all post-socialist countries facing the reality of Pride marches in their urban spaces. 
modus operandi of the Metropolitanate of Moldova: informal agreements with the government where concessions used to be exchanged for ecclesiastical loyalty.

There are at least two reasons why the mainstream Church remains unwilling to set itself against state authorities even while disapproving of specific policies. First of all, whilst trusting the Church, people distrust its bishops and the clergy in general, because many priests are involved in commercial activities which include selling and renting out the property of parishes (Chebotar 2018). Some bishops are seen to be living luxuriously: in 2014 a tabloid published some photos of Metropolitan Vladimir vacationing with a woman, and other compromising details (Moşneag 2014). ${ }^{6}$ In 2017 there was a widely negative response to a birthday party for the Bishop of Ungheni, Petru Musteață (YouTube 2017). According to Nikolae Fuştei, Petru was from the very beginning a controversial figure: in 2005 his ordination provoked a split, and forty parishes (of one hundred) left and joined the Bessarabian Metropolitanate (Fuştei 2011). At the same time, it is normal for priests to have to do jobs on the side, and even become migrant labourers; for example, one cleric works in the UK at a poultry farm (Florinskii 2019). Fuştei stressed that:

It sounds strange but in all the surveys enquiring into which institution in the country is the most trusted - the Church, gets about eighty per cent. But people do not equate bishops with the Church. That is why during the elections less than one per cent voted for

6 Some internet commentators expressed their satisfaction that Vladimir was, at least, not gay; later on the Metropolitan publicly claimed that the woman was his niece. the party which the Metropolitan had called on the public to vote for. Imagine: eighty per cent think that the Church is the most authoritative and trustworthy institution, and, at the same time, less than one per cent vote for someone who appears to be campaigned for by the church. (Fuştei 2011)

Fuştei refers to the 2010 parliamentary elections, when Metropolitan Vladimir openly supported Valery Pasat's party, ${ }^{7}$ and even permitted use of a photo of them together in the campaign. Pasat won only 0.9 per cent of the vote, and since then Metropolitan Vladimir has never participated in political campaigns.

The second reason why the mainstream Church is interested in good connections with the government is due to its inability to reach beyond the stratum of 'traditional believers' interested in a limited set of services: baptisms, weddings, and funerals. In Russia the Church faced the same problem at the end of the 1980s, but was able to resolve it, or postpone dealing with it, thanks to a large influx of young neophytes. Orthodoxy in Moldova never fully disappeared from the lives of the people; but it was never an object of acute neophytic interest. The local clergy was not ready for the fact that the older generation of parishioners will simply pass away (or for the role played by migration); they have no idea of how to replenish their flock. The Metropolitanate of Moldova has no social department, even, and Fr Octavian Moşin has to deal with social projects, formally being responsible only for the youth. He regrets that only a few parishes conduct some non-religious social projects:

7 Valery Pasat (b. 1958) is a Moldovan politician who in 2010 was the head of the Humanistic Party. 


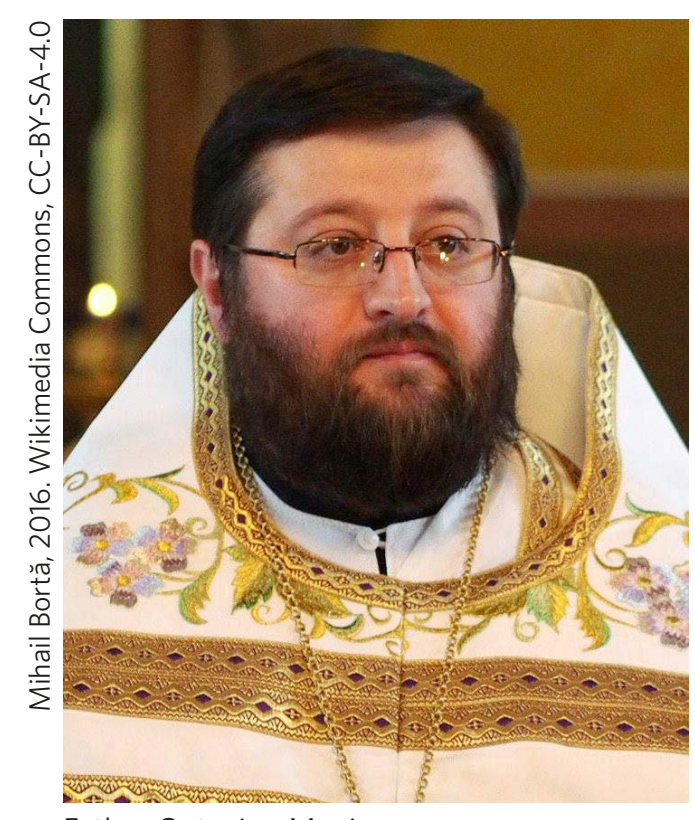

Father Octavian Moșin.

There are no young people in the parishes. Everyone leaves, so, in the parishes there are only old people. I think - it is our first problem. Second, there are no specific projects to involve the young people... It gets harder and harder every year. (Moșin 2019)

I pay this much attention to social and youth work, because in contemporary society organised religions have to compete with more attractive ways of spending time. Providing space for socialization (for example, through social volunteering) attracts new, younger parishioners. A disadvantage of the youth and social work in the Metropolitanate of Moldova is that Church-sponsored events are mostly designed for people already deeply involved in ecclesiastical life (e.g., reading the Bible, joint prayers, celebrating holidays, etc.). As a result, 'silent marches' are scantly attended: 'A few tens of people come, not more... Mostly people of the Church, I mean - priests, their families, and so on... As for [people] from the parishes - maybe one, or two' (Moșin 2019). Fr Cheibaş also confirmed that it becomes more difficult to gather our people around this idea' (Cheibaş 2019).

In the absence of significant public support, the Church gradually returns to its bargaining strategy. The Metropolitanate had already engaged in unofficial talks with the prospect of not only changing the legislation on equality, but also reintroducing a regulated religious market:

There are also promises from the Socialist party, the party of the president, in this regard; and from the Democratic party too. A month ago we had meetings with the chair of the Democratic party, which is the ruling one now in Moldova, and they also promised somehow to change all that... to add this phrase, the syntagma that state should support the Church.

Question: The Church, not religions in general?

Answer: Religions, of course; but, as Lenin used to say: 'we say one thing, but we mean another'. (Cheibaş 2019)

Fr Cheibaş expects a levelling of the income gap between the urban and the rural clergy and channelling of European subsidies into the historical monasteries:

All the spiritual potential of Moldova at the other side [i.e. Romanian inner Moldova] has been renovated thanks to these funds. Each monastery got two or three million [euros]. It is so far impossible for us, because all the money from the European Union are transferred through the government. (Cheibaş 2019) 
Fr Cheibaş added that the Metropolitanate is concerned about not repeating the Ukrainian scenario, where the government explicitly supported the new autocephalous church: 'We should not forget what has happened there [in Ukraine] and should find our golden mean in this friendship with political leaders in order to protect our identity' (Cheibaş 2019). Although the formation of a rival autocephalous Church in Moldova is hardly likely in the foreseeable future, relocation of state support to the existing Bessarabian Metropolitanate represents a real danger.

Ian Feldman evaluates the hopes of the Metropolitanate as 'wishful thinking' (Feldman 2019); he is right, because in a country whose population heavily depends on working in Europe no party would be brave enough to amend agreements concerning visa liberalization. Igor Dodon, the President of Moldova, looks like a reliable supporter for the Metropolitanate of Moldova, but the situation is not that simple. Dodon tries to instrumentalize the issue of LGBT equality by presenting himself as a protector of traditional family values. Apart from participating - with his family - in the 'silent marches', he initiated an annual 'Festival of Family'. The year 2019 in Moldova is proclaimed the 'Year of the Family'. Under Dodon's patronage, in September 2018 Chişinău hosted the World Congress of Families (IOF website). Fr Cheibaş stresses that the congress was not organised by the Church (Cheibaş 2019). Metropolitan Vladimir did not even address the forum; neither did Patriarch Kirill, although Dodon planned to invite him to Moldova precisely for the event.

The presidential address at the closing session of the World Congress of Families had not much in common with the agenda, but was full of references to the political situation in Moldova. He tried to present
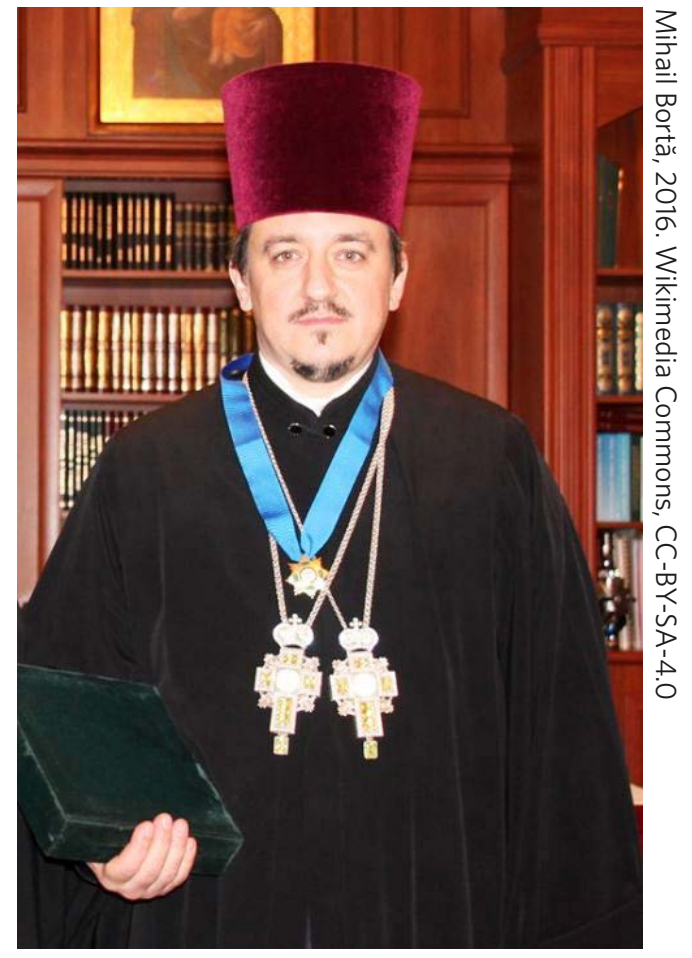

Father Vadim Cheibaș.

himself as a leader promoting Moldovan sovereignty and the unity of all ethnic groups. ${ }^{8}$ His message, apparently designed for a wider domestic audience, presented an enigma to the foreign delegates:

We will preserve and defend our
essence, identity, and values. For it is
sacred for us. It is all we have. We have
no strong army; we have no gas and oil.
We have people, we have traditions,
we have faith, and we have history. We
are strong thanks to it - without army,
without oil, without gas. Why destroy
all this? (YouTube 2018a)

Dodon's backing in many ways can be said to undermine the Metropolitanate,

8 He spoke in Russian, stressing that more than one million Moldovan citizens use this language. 
whose pro-family initiatives are seen by the general public as political rallies in support of Dodon. The Metropolitanate has to strike a balance between the president and his political adversaries: 'One political structure is sympathetic to the East, one political structure is sympathetic to the West. So far this balance is very... favourable for the Orthodox Church' (Cheibaş 2019). In spite of many verbal condemnations of European integration previously made by the Synod and by Metropolitan Vladimir personally, Fr Cheibaş rounded off with the statement that 'If the state is already oriented towards this process - can the Church ever be against it?' (ibid.)

Priests on the whole are not so moderate. Fr Vitalii Shinkar says that 'the main European value is pederasty' (Shinkar 2019). In 2018 he was one of the four priests (including Marchel, the Bishop of Bălți and Fălești) who were fined in 2016 for insulting a presidential candidate Maia Sandu: they said that she was 'barren' (i.e., not married and without children in her forties) and a danger to Christian society because of her tolerant attitude to sexual minorities (Privesc.eu 2016). The Metropolitanate of Moldova neither stood in solidarity with these priests, nor issued any letters in their support. Not once did Metropolitan Vladimir threaten to defrock Bishop Marchel for his participation in street protests against the new legislation.

\section{The radicals: the end is nigh}

The radicals are a loose community of the clergy and laity, partly organised around small formal and informal groups, of which the most well-known are the Asociaţia Fericita Maică Matrona ('Blessed Gerontissa Matrona') headed by Archpriest Anatolie Cibric (see Ulmanu 2013; Mitrofanova, forthcoming), and the Pro Ortodoxia association led by Deacon Ghe- nadie Valuța. Originally they derive from the Moldovan Orthodox Church and share the same ideology, but disagree about the means to implement it.

These people are a social and ecclesiastical minority; sometimes the Council for the Prevention and Elimination of Discrimination and Ensuring Equality protects their rights as well. Feldman recalls that someone, apparently from the radical Orthodox milieu has applied to the council because without an enumerated ID card, he was granted no access to medical services:

The Council, having considered his case, said that it was, in our opinion, discrimination... State should find out how to protect the rights of this small group of people... We have sent a copy of the decision to the Metropolitanate of Moldova, but there was no reaction. And this man, when he came to me, he said: as I was going to you, I thought that there would be truly demonic scum here, that you were for gays only; but you were the only people, with whom I found understanding of my situation, support, and you even made a decision in my favour. (Feldman 2019)

The radicals have a clear understanding of why they oppose the normalization of homosexuality. The mainstream Church mostly refers to the obscure discourse of 'traditional values', admitting (at least, at the level of ordinary priests), that in contemporary Moldova one can only speak about some persistent rural traditions, gradually withering away because of urbanization; 'the traditions to decorate churches with rags' (Florinskii 2019). So far the Metropolitanate of Moldova has produced no published material as a theological foundation for its opposition to 
homosexuality. The 2014 document condemning gay parades contains only one, moderate, reference from the Bible (2 Cor. $6: 17)$. In this light, it becomes problematic for the clergy to explain theologically why they oppose the Pride marches, and Fr Florinskii has resorted to rhetorical questions: 'Why is the Church against them? And why do you not eat glass?' (Florinskii 2019). The ambiguity of the term 'traditional values' allows Ian Feldman to claim semi-seriously that his Council is, actually, the main defender of these values, because it 'protects values of maternity, values of supporting the seniors, etc.' (Feldman 2019).

Explanations provided by the radicals are much more theologically refined, and this is mostly to the credit of Viorel (Venedict) Ciubotaru - an independent journalist and thinker who used to be associated with 'Blessed Gerontissa Matrona'. First, he articulated ethical arguments against the newly adopted Law on Ensuring Equality:

First time at the level of legislature some things being wicked, bad, abnormal, are proclaimed equivalent to the normal... the horror of this law is that the evil, in fact, is proclaimed a variation of the good. (YouTube 2012)

Then, Ciubotaru proceeded to more profound themes, presenting homosexuality as something ontologically vicious, able to distort God-created human nature and to destroy the likeness to God in human beings:

By this law, in fact, the very notion of human is being eliminated in us, because a human is a being able to distinguish between the good and the evil... If we base on the European values, the new type of human is pro- duced, previously unknown to history: I would call it anti-human.

(YouTube 2012)

The rhetoric of traditional values seems to be irrelevant for the radicals; Fr Cibric says that 'traditional values mean betrayal... in the past people just lived in accordance with these values and did not protect them' (Cibric 2019). None of the radicals participated in the Congress of Families.

Another difference between the mainstream Church and the radicals is that the latter refuse to accept the unwritten pact of friendship with the government. According to Fr Cibric, 'one should not play by the rules of a gangster; and they [the Metropolitanate of Moldova] play by the rules of a gangster' (Cibric 2019). While the Metropolitanate writes letters to the president and the parliament, the radicals are becoming engaged in direct political activism - from protest camps to street fighting. Since 2013 they have organised counterdemonstrations to interrupt and disperse 'gay parades' (of which none looked like a gay parade in the European sense). Riot police guarding the Pride marches was particularly violent towards the radicals in 2018. The Metropolitanate expressed its disapproval of violence, distancing itself, at the same time, from the anti-Pride protests:

We [the Metropolitanate] have good relations with the police. And in case such clashes with demonstrators happen... well, they also want us to understand their position, because they have to keep order... Policemen themselves are sort of against this idea [of the Prides], these minorities, at the same time they have to keep order. (Cheibaş 2019) 
Those protest marches against the gay parade were not organised by the Church. It comes more like society's reaction. I would not say that only the Orthodox, or only the believers participated there; it was society, I mean, people, who are against this phenomenon, against gay parades. (Moşin 2019)

Activities of the radicals are directed against the mainstream Church not less than against state policies. In summer 2014 Fr Ghenadie Valuța initiated a twomonths' protest camp along the fence of the Metropolitanate building, demanding an official condemnation of the Law on Equality and of the Pride marches: the above-mentioned document on gay parades, as well as another paper directed against European integration in general, were adopted by the Synod under pressure from below. Both documents are now available at the official ecclesiastical website only in their scanned versions, which makes finding them complicated. Fr Valuța was then temporarily suspended; there are persistent rumours that one of the reasons was that he had been involved in publicising the notorious pictures of Metropolitan Vladimir (Vedomosti 2015).

The radicals claim that the Church lacks sobornost ('conciliarity'), and this makes it unable to defend Christian values. This issue was brought to my attention by Nicolae Fuştei:

Many priests let themselves ask: where is the conciliar principle (sobornoe nachalo) of the Orthodox Church in Moldova, why is everything decided by one person? However smart he may be, but he cannot know everything, and he cannot control everything. It is the Church, the body of Christ ... where every member is important for the life of the organism. (Fuştei 2011)

Nikolai Fuştei and Viorel Ciubotaru have very low opinions of each other; nevertheless, both do not want one person in the Church to decide for all:

The Metropolitanate cannot be reduced to the personality of the Metropolitan. The Metropolitanate, if it is a Church, and not a private office of citizen Vladimir Cantarean, working as the manager of this office, embraces all Orthodox members in its territory... All decisions in the Church should be made on a conciliar basis (soborno). (Vedomosti 2014)

Since around 2016, many radicals have ceased to pray for Patriarch Kirill and Metropolitan Vladimir during liturgical services - such believers are known in the Russian Orthodox Church as 'nonmentioning. The split was triggered by the Patriarch's meeting with the Pope in Havana. Viorel Ciubotaru joined the nonmentioning side earlier on the ground of a 'homosexualization' of the mainstream Church:

According to the canons of the Church citizens Filat, Timofti, Prime Minister Leancă, Ministers of Justice (Efrim and Tănase) and all the 53 deputies, who have voted for the law on homosexualization, for lifting the ban on homosexual propaganda among minors, should be anathematized. Instead, citizen Vladimir Cantarean has awarded these people represented by Filat the Order of Appreciation. This means that the Metropolitan is not with the Orthodox Church, but with the 'Satanic gathering', which 


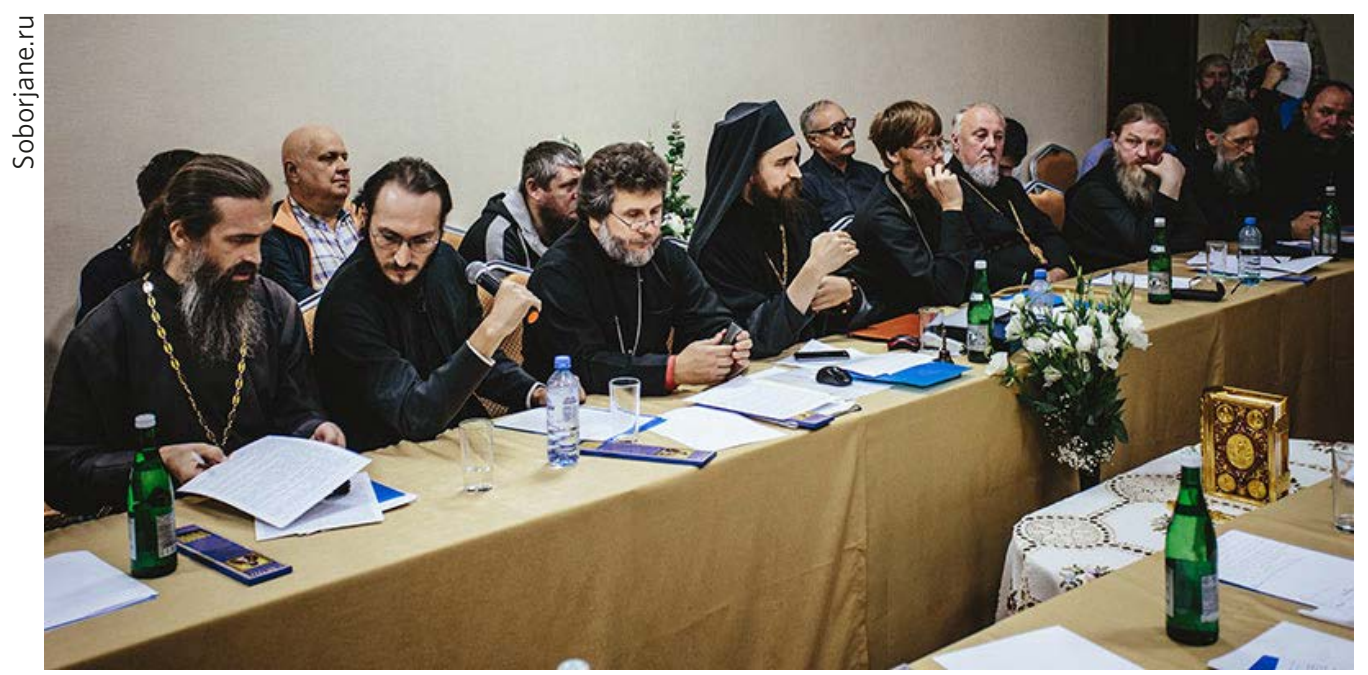

Assembly of the non-mentioning priests in Krasnodar, Russia, 5.10.2017. Fr Cibric is third from the left.

is what the existing government is. (Vedomosti 2014)

The non-mentioning group do not envision themselves as schismatics, insisting that they remain within the Church, while the Patriarch and bishops have excommunicated themselves:

The Metropolitan is doing strictly heretical deeds, having no relation to Orthodoxy, as well as his secretary Archpriest Vadim Cheibaş. The Metropolitan, doing what is contrary to Orthodoxy, becomes a false bishop and, by this, he loses the apostolic succession, ceasing to be the member of the Orthodox Church. (Vedomosti 2014)

The absence of the bishops needed to ordain new priests is a problem for the nonmentioning believers. Father Vasilie says that they have a plan to ordain as bishop a hieromonk from Răciula Monastery; Archimandrite Pafnutie, an active participant of rallies against homosexuality (YouTube 2018b). Pafnutie forbids his spiritual children to attend liturgies where people pray for the Patriarch, and to consume liturgical bread given by loyal priests, recommending them 'to dispose of it' (Vasilie 2019). It is unclear which nonmentioning bishop is expected to ordain Pafnutie, but according to Vasilie this must be someone from Ukraine.

The radicals are backed by some mainstream hierarchs, of whom Marchel, Bishop of Bălți and Făleşti, is the most high profile. ${ }^{9}$ External observers suggest that 'this specific activity of Marchel depends on his wish to become the Metropolitan of Moldova... If this happens, at the moment he becomes the Metropoitan (if and when), he will change his rhetoric' (Feldman 2019; see also Esp.md 2012). Anyhow, Marchel seems uninterested in joining the nonmentioning group, although they are in urgent need of a bishop.

What is not fully clear is why none of the non-mentioning priests has yet been suspended. Fr Cibric insists that

9 Bishop Petru of Ungheni is also supportive of the radicals; Archimandrite Pafnutie belongs to his bishopric. 
Metropolitan Vladimir 'knows for sure that I am right', and admits that he has once said to Vladimir: 'I pray for you secretly' (Cibric 2019). A mundane explanation is that the Moldovan Church, after 27 years of performing a 'balancing act' has become dangerously fragmented and sometimes appears as a collection of independent parishes. Nicolae Fustei stresses that:

[People] look for a faithful priest, and they are not interested in which jurisdiction this priest is... These priests are authoritative, naturally, for their parishes. And one can see, which church has an authoritative priest, and which does not: just enter this church during Liturgy, and look, which church is empty and where people are standing even in the street and listen to the Liturgy. (Fustei 2011)

Fr Nikolai Florinskii agrees that each Moldovan priest is 'the Patriarch in his parish', 'distanced from Moscow, ...distanced from Bucharest' (Florinskii 2019). This fragmentation does not allow the Metropolitan to dispose of 'authoritative' priests, while risking loss of their flock too. The above-mentioned Pafnutie is an example of such priests, thanks to his assertive and emotional style of preaching, even going so far as (according to Fr Vasilie) bursting into tears.

Police violence in 2018 had diverted the radicals from physically confronting the Pride demonstration in May 2019. Fr Cibric deemed street fights to be useless because the time of Judgement had come and 'we were waiting for the end' (Cibric 2019).

\section{The Bessarabian Metropolitanate: a nascent 'public' church}

In October 1992, when the assembly of the Moldovan clergy decided to stay within the Moscow Patriarchate, a group of clerics broke away. To admit them, the Romanian Church restored its Bessarabian Metropolitanate, open to priests and parish communities wishing to leave the jurisdiction of the Russian Church in Moldova and Ukraine (see Avram 2014). Although the Russian and Romanian Churches remain in Eucharistic communication, in Moldovan territory the flock of the Metropolitanate of Moldova is not in communion with the Bessarabian Metropolitanate.

The Romanian Church has its own history of confronting equal opportunities policies in Romania, but without any significant results (see Conovici 2009-10; Cirlan 2019). A referendum held in 2018 was the last initiative of the conservatives; its purpose was to secure that marriage would be defined as a union between a man and a woman. Fr Ioan Cosoi, secretary of the Bessarabian Metropolitanate, said that in the days of the referendum the Bessarabian priests in Moldova 'were saying in all parishes that those who possess Romanian citizenship must go to the referendum, because its subject was good and we must protect our children, our future' (Cosoi 2019). The referendum, nevertheless, failed because of a low turnout. According to Fr Cosoi, his bishopric is concerned with traditional values, but works 'at the other level': 'in the Metropolitanate of Moldova there are groups of people who go out to protest. We do not have such a policy to go out and protest' (ibid.). Ian Feldman confirms that he has never heard 'strong statements' from the Bessarabian priests (Feldman 2019).

The 'other level' refers to systematic social and youth work done by the Romanian Church. Fr Cosoi has shown 
me a shelter for single mothers abandoned by their families, and a 'social apartment' where girls from families in crisis can live for a year and learn useful trades. Social projects are run by volunteers and paid employees; steady parishioners and non-believers. Volunteers are attracted by three things: opportunities for professional development while working for projects; 'volunteer cards' which may later help holders to enrol into a university; and 'showing the other side of the Church - namely social influence. If they have their own place, and this place is very important, they can make decisions in our organization, they come' (Cosoi 2019). Speaking the language of the market, however, the Bessarabian Metropolitanate is sponsored by the Romanian state and the European Union, while the Metropolitanate of Moldova has no external financial resources. At the same time, the Russian Orthodox Church (also having no such resources) has initiated its

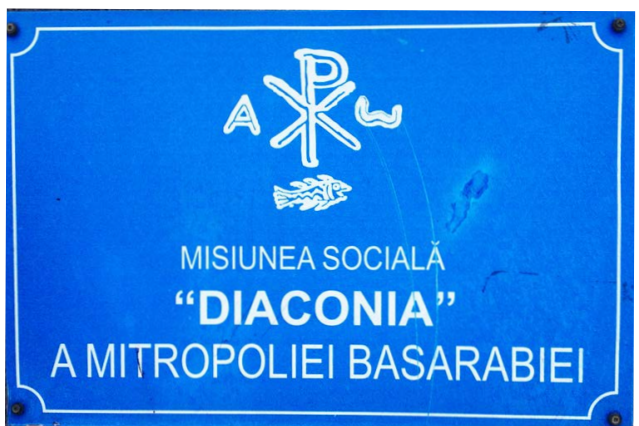

Headquarters of the social division of the Bessarabian Metropolitanate in a remote district of Chișinău.

own social work system, analogous to the Romanian 'Diaconia', and already provides grants for NGOs. The Moldovan Church, as I concluded from the interview with Fr Moşin, does not do, or plan, anything similar.

According to Fr Cosoi, his faith community experiences depopulation problems comparable with those of the Moldovan Orthodox Church:

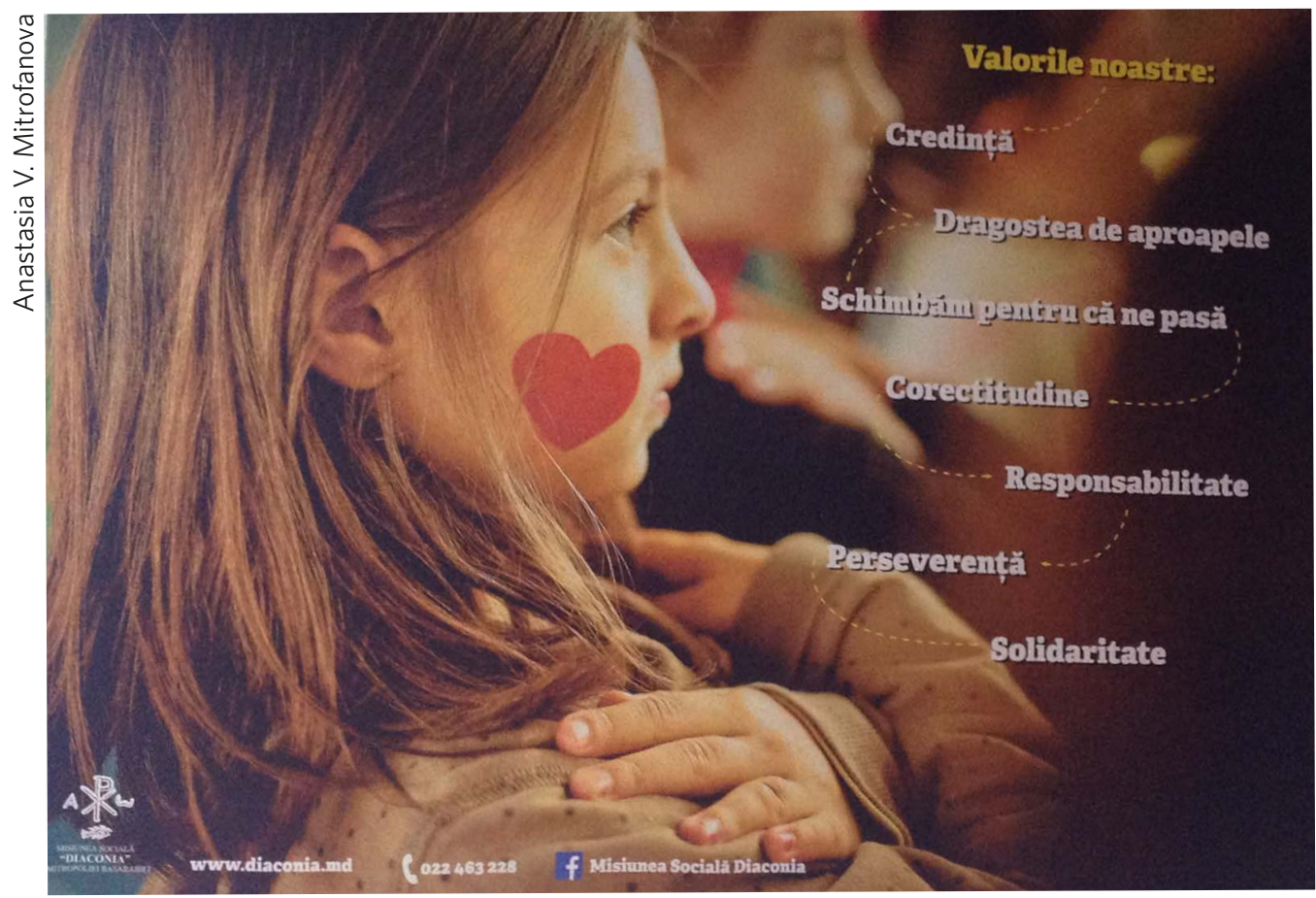

Poster of the social work conducted by the Bessarabian Metropolitanate in Moldova. 
Our villages are dying now, because all the young people leave villages, leave for cities - move here, to Chișinău, or abroad... When I was young, I mean - at school - our parents moved out, but they moved out to come back with money, to build a house and so on. Now they leave, then they come back, take their families, and all of them leave. I talked to our priests, and they say: Father, when I came to my parish in 91, or in 93, or in 95, I had one hundred baptisms there, one hundred weddings; and now I have two or three in a whole year, but one hundred funerals. (Cosoi 2019)

The Bessarabian Metropolitanate has chosen its own strategy for adaptation: to be a European-style church that remains deeply involved in social life, providing assistance to those in need, but stays within the framework set by the democratic state. Jose Casanova has called it 'public religion' (Casanova 1994: 57). Being a 'European church' presumes also some level of democratization. Fr Cosoi says that even the negative media coverage of the Metropolitanate of Moldova is harmful for the Orthodox Church as a whole:

We have some bishops, and they are like barons, they have luxury, live luxurious lives... There was that birthday party for Bishop Petru from Ungheni... Generally, the Orthodox Church as such should now demonstrate great humility: that you are a humble man, one of us... (Cosoi 2019)

The social activism of the Bessarabian Metropolitanate does not make it popular: so far it has attracted about ten per cent of the priests (Florinskii 2019); the exact number of parishes is unknown, but it is much lower than at the Metropolinate of Moldova. While it is sociologically proven that most people in Moldova declare that they have a specific Moldovan identity (Kirillov and Putintsev 2018: 44), this bishopric insists that the Moldovans are a regional variation of the Romanians. It is not that the Bessarabian parishes are attended only by believers with a Romanian identity, but such people do feel more comfortable there. Another problem of this bishopric is that sometimes it offers solutions tailored for a society with much longer history of Europeanization. The position of the Romanian Church in Romania is much stronger than the position of its Bessarabian Metropolitanate, because the Romanian Church has been changing in step with with Romanian society, or even much more slowly. In Moldova the Bessarabian Metropolitanate is at the moment more Europeanized than its potential followers.

\section{Conclusion}

Under the conditions of a deregulated religious market, key Orthodox actors in Moldova explore three different strategies to win public support.

Since its formation in 1992 the Metropolitanate of Moldova has struck a balance between political groupings and relied on private bargains with their leaders. Splits in the political class played into the hands of the Church, because each faction tried to present the Metropolitan as its supporter. This policy of 'balancing' came to the end with the adoption of the Law on Ensuring Equality, and the religious monopoly of the Church began to wither away. Recently, the Metropolitanate has tried to assimilate the strategies of street politics, characteristic of the competing radical groups, but without any visible success. Ordinary believers are less and less inclined to participate 
in the initiatives of the Metropolitanate. Priests and bishops pursue their private goals, and the Church remains united only by Metropolitan Vladimir, to whom people remain personally loyal. The rise of competing 'religious suppliers' from within continuously undermines the influence of the Metropolitanate. The latter strives to bring back a regulated religious market, and even speaks in support of Europeanization, as long as this concept entails state support of churches.

The Bessarabian Metropolitanate seems well equipped for finding its place in the changing social order. It utilises the strategies of the European 'public' churches and gains social influence through performing useful social functions without pretending to be the spiritual guide of society as a whole. At the same time, in terms of the market theory of religion, providing non-religious communal services attracts 'free riders' rather than devout believers (Iannaccone 2012: 113). Compared with the 'outdated' Moldovan Church, the Bessarabian Metropolitanate has surprisingly few followers (although its numbers may grow with years). As a result, it needs financial support from Romania and the EU, and has to serve a 'market niche' of believers with a strong Romanian identity. To reach beyond this stratum, this bishopric needs to admit that most people in Moldova see themselves as a sovereign nation; this, however, would hardly be possible for the Romanian Church in general.

The radicals are a competing group that almost split from the erstwhile monopolistic Church. They utilise the strategy of direct action, involving their supporters in street-political carnival activities. Their opposition to the equal opportunities legislation is strongly expressed, and they are able to satisfy the need for authoritative ecclesiastical leaders. The radicals are not associated with concrete political figures and are open to coalitions with other like-minded actors, for example, with conservative Protestants. There are, however, important factors playing against them. First, the radicals are relatively few, and not supported by the Church - the latter remains important in Moldova. Second, the state becomes more and more persistent in persecuting the protesters. Third, the radicals demand too much of those who join them. Their struggle is not just against some bad legislation; they see the political situation through apocalyptic lenses, encouraging people to destroy their documents and to hide in the forests. As a result, the radicals serve a narrow market niche for people seeking a 'high-tension religious option' (Stark and Finke 2000: 197; see also Iannaccone 2012). It is important for them not to exceed any 'limit to strictness' (Iannaccone 1994: 1201-4); but the radical movement may even enjoy limited popularity if it manages to avoid marginalization.

So far the Metropolitanate of Moldova remains the strongest Orthodox actor, potentially able, unlike its niche-oriented competitors, to reach the wider society. Unfortunately, this strength owes much to what Rodney Stark and Roger Finke (2000: 201) define as cultural inertia, that delays the acceptance of new religious suppliers. Restoration of the religious monopoly is hardly possible, but the Metropolitanate remains not fully confident about attracting young urbanites and mobilising parishioners for political rallies. Its social and youth work remains sporadic. Adopting the strategies of 'public churches' (probably borrowed from the Russian mother church) would make the Metropolitanate a stronger religious competitor. The ecclesiastical message concerning equal opportunities will be, in this case, better heard by society and the government. Nevertheless, even having 
increased its influence, the Metropolitanate would never radicalize because of its fear of repeating 'the Ukrainian scenario'.

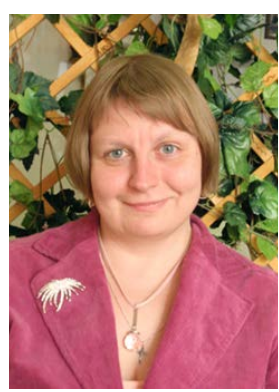

Anastasia V. Mitrofanova is Leading Research Fellow at the Institute of Sociology of the Federal Centre of Theoretical and Applied Sociology at the Russian Academy of Sciences; she is also Professor at the Financial University under the Government of Russia and at the Russian State University for the Humanities (RGGU). She received her MA (1994) and PhD (1998) from the Moscow State University, and her Dr.habilitat degree from the Diplomatic Academy of the Foreign Affairs Ministry of Russia (2005). Mitrofanova's research interests include religious politicisation, fundamentalism, Orthodox Christianity and politics, nationalism in post-Soviet states, religiopolitical movements. Her main publications are Politizatsiia 'pravoslavnogo mira' (Moskva, Nauka, 2004); The Politicization of Russian Orthodoxy: Actors and Ideas (Stuttgart, Ibidem-Verlag, 2005).

\section{List of References}

Interviews by Anastasia V. Mitrofanova

Cheibaş, Vadim. Chișinău, 23.1.2019

Cibric, Anatolie. Chișinău, 27.1.2019

Cosoi, Ioan. Chișinău, 25.1.2019

Efrim, Oleg. Chișinău, 23.8.2013

Feldman, Ian. Skype-interview, Moscow-

Chișinău, 29.4.2019

Florinskii, Nikolai. Chișinău, 26.1.2019

Fuştei, Nicolae. Chișinău, 5.2.2011

Moșin, Octavian. Chișinău, 23.1.2019

Shinkar, Vitalii. Chișinău, 26.1.2019

Vasilie, priest. Chișinău, 25.1.2019

\section{Literature}

Avram, A., 2014. 'Orthodox Churches in Moldova', Eastern Christianity and Politics in the Twenty-first Century, ed. L. Leustean (London, Routledge), pp. 402-25

Ayoub, Phillip, and David Paternotte (eds.), 2014. LGBT Activism and the Making of Europe: A Rainbow Europe? (Basingstoke, Palgrave Macmillan)
Bilic, Bojan (ed.), 2016. LGBT Activism and Europeanisation in the Post-Yugoslav Space: On the Rainbow Way to Europe (Basingstoke, Palgrave Macmillan)

Biserica Ortodoxă din Moldova, 2014. 'S-a încheiat prima zi a ședinței Sinodului Bisericii Ortodoxe din Moldova Condamnarea paradelor gay și a consecințelor adoptării Legii cu privire la Egalitatea de Șanse', Biserica Ortodoxă din Moldova, 3.9.2014, $<$ http://mitropolia.md/s-a-incheiat-prima-zi-a-sedintei-sinodului-bisericii-ortodoxe-din-moldova/> (accessed 31.5.2019)

Casanova, Jose, 1994. Public Religions in the Modern World (Chicago and London, The University of Chicago Press)

Chebotar, A., 2018. 'Tserkov Gospoda, narodnye dengi i OOO sviashchennika', Ziarul de Gardă, 16.8.2018, <https://www.zdg.md/ $\mathrm{ru} / ? \mathrm{p}=20213>($ accessed 31.5.2019)

Chesnut, Andrew, 2003. Competitive Spirits: Latin America's New Religious Economy (New York, Oxford University Press)

Cirlan, Lucian, 2019. 'From criminalization to gay marriage: homosexuality in the discourse of the Romanian Orthodox Church after 1989', paper presented at the conference 'Histories of Religion and Homophobia in Eurasia, Oxford, 11-12.4.2019

Conovici, Iuliana, 2009-10. Ortodoxia în România postcomunistă. Reconstrucţia unei identităţi publice, vol. I-II (Cluj-Napoca, Eikon)

Drissel, David, 2016. 'Rainbows of resistance. LGBTQ pride parades: contesting space in post-conflict Belfast', Culture Unbound, 8(3), pp. 240-62

Esp.md, 2012. 'Nantoi: “Episkop Markell khochet podsidet Mitropolita Vladimira", Beltskii nezavisimyi portal, 31.5.2012, <https://esp. $\mathrm{md} / 2012 / 05 / 31 /$ nantoj-episkop-markel-xochet-podsidet-mitropolita-vladimira $>$ (accessed 31.5.2019)

Ganzevoort, R. Ruard, and Srdjan Sremac (eds.), 2017. Lived Religion and the Politics of (In)Tolerance (Basingstoke, Palgrave Macmillan)

Iannaccone, Laurence R., 1994. 'Why strict churches are strong', American Journal of Sociology, 99(5), pp. 1180-1211

- -1997. 'Introduction to the economics of religion', Journal of Economic Literature, 36(3), pp. 1465-95 
- -2012. 'Extremism and the economics of religion', The Economic Record, 88, pp. 110-15 Igrutinović, Danica, Srdjan Sremac, and Mariecke van den Berg, 2015. 'Pride parades and/or prayer processions: contested public space in Serbia \#Belgrade Pride', Journal of Empirical Theology, 28, pp. 1-22, <https:// doi.org/10.1163/15709256-12341330>

IOF website. International Organization for the Family, <https://www.profam.org/> (accessed 23.9.2019)

Iordache, Romanita, 2018. 'The dichotomy between Europeanisation and the revival of Moldovan Orthodoxy: the strategy of the Moldovan Orthodox Church', Relation to Equality Legislation Orthodox Religion and Politics in Contemporary Eastern Europe on Multiple Secularisms and Entanglements, ed. Tobias Köllner (London, Routledge), pp. $145-56$

Kargina, Irina, 2014. Sotsiologicheske refleksii sovremennofo religioznogo pliuralizma (Moscow, MGIMO-Universitet)

Kirillov, Viktor, and Igor Putintsev, 2018, 'Vliyanie Rumynii v Moldavii: formy i evoliutsiya unionizma', Sovremennaia Evropa, 3, pp. 37-48, <http://dx.doi.org/10.15211/ soveurop67e320183748>

Lehmann, David, 2010. 'Rational choice and the sociology of religion', The New Blackwell Companion to the Sociology of Religion, ed. Bryan S. Turner (Hoboken NJ, Wiley-Blackwell), pp. 181-200

Lex.justice.md, 2012. Zakon Nr. 121 ot 25.05.2012 ob obespechenii ravenstva, Lex. justice.md, <http://lex.justice.md/index. php?action=vza ' ' 'swadew\&view=doc\&la $\mathrm{ng}=2 \& \mathrm{id}=343361>($ accessed 31.5 .2019$)$

Mitrofanova, Anastasia, forthcoming. 'Questioning the European path: Orthodox political radicalism in contemporary Moldova, manuscript submitted to Religion, State and Society

Moşneag, Victor, 2014. 'Mitropolitul de milioane (II). Casa de lux şi femeia din spatele ÎPS Vladimir', Ziarul de Gardă, 11. 8.2014, $<$ https://www.zdg.md/editia-print/investigatii/mitropolitul-de-milioane-ii-casa-delux-si-femeia-din-spatele-ips-vladimir > (accessed 31. 5.2019)

Privesc.eu, 2016. 'Conferință de presă susținută de un grup de preoți în frunte cu episcopul de Bălți și Fălești, Marchel', Privesc. eu, 4.11.2016, <https://www.privesc.eu/ arhiva/69920> (accessed 31.5.2019)

Slootmaeckers, Koen, Heleen Touquet, and Peter Vermeersch (eds.), 2016. The EU Enlargement and Gay Politics: The Impact of Eastern Enlargement on Rights, Activism and Prejudice (Basingstoke, Palgrave Macmillan)

Sremac, Srdjan, and R. Ruard Ganzevoort (eds.), 2015. Religious and Sexual Nationalisms in Central and Eastern Europe: Gods, Gays and Governments (Leiden, Brill)

Stark, Rodney, and William S. Bainbridge, 1987. A Theory of Religion (New York, P. Lang)

Stark, Rodney, and Roger Finke, 2000. Acts of Faith: Explaining the Human Side of Religion (Berkeley, University of California Press)

Stark, Rodney, and Laurence R. Iannaccone, 1994. 'A supply-side reinterpretation of the "secularization" of Europe, Journal for the Scientific Study of Religion, 33(3), pp. 230-52

Ulmanu, Alex, 2013. " Tolerance is the failure to resist evil": Moldova's leading religious fundamentalist has a violent message for the west', The Black Sea: Diving Deep into Stories, 17.12.2013, <https://theblacksea. $\mathrm{eu} /$ stories/culture-clash-in-moldova-orthodox-fundamentalism-rallies-to-attack-the-west/> (accessed 31.5.2019)

United Nations, 2012. Report of the Special Rapporteur on freedom of religion or belief, Heiner Bielefeldt. Mission to the Republic of Moldova, United Nations, January 27, <https://digitallibrary.un.org/ record/722491> (accessed 8.9.2019)

Vedomosti 2014. 'Viorel Chiubotaru: voiti v Evropu oznachaet vyiti iz pravoslaviia', Moldavskie Vedomosti, 20.1.2014, <http://www. vedomosti.md/news/Viorel_Chibotaru_ Voiti_V_Evropu_Oznachaet_Vyiti_Iz_Pravoslaviya_> (accessed 31.5.2019)

- -2015. 'Istoriia fotografii mitropolita s zhenshchinoi ne zaconchilas', Moldavskie Vedmosti, 4.9.2015, <http://www.vedomosti.md/news/istoriya-fotografij-mitropolita-s-zhenshinoj-ne-zakonchilas> (accessed 31.5.2019)

Young, L. (ed.), 1997. Rational Choice Theory and Religion: Summary and Assessment (London, Routledge)

YouTube 2012, "'Otkrovennyi dialog" - gost Viorel Chiubotaru', AlfaNews MD, 29.5.2012, 
$<$ https://www.youtube.com/watch?v=zyLprRGq_FU> (accessed 31.5.2019)

-—2017. 'Serata Jubiliară dedicată aniversării a 50 de ani a Preasfințitului Petru', Vadim Corostinschi, 2.11.2017, <https://www. youtube.com/watch? $\mathrm{v}=1 \mathrm{ckGBPpdxN} 4>$ (accessed 31.5.2019)

- -2018a. 'XII Vsemirnyi Kongress Semei (Dodon, Smirnov, Osipov)', Missiia OD, 19.9.2018, <https://www.youtube. $\mathrm{com} /$ watch?v=Eh-TrNoujEY> (accessed 31.5.2019)

- 2018b. 'Cuvântul Părintelui Pafnutie, 31 mai 2018 izestrea', 7.6.2018. <https:// www.youtube.com/watch?time_continue $=4 \& v=4$ LidH8wfI $44>\quad$ (accessed 31.05.2019) 